\title{
DAMPAK PENGUMUMAN RIGHT ISSUE TERHADAP SHAREHOLDER WEALTH DI BURSA EFEK JAKARTA
}

\author{
Masruroh $^{1}$
}

\section{ABSTRACT}

Article clarifies the impact of right issue announcement on abnormal return that will influence the prosperity of share holder. A research about right issue is an event study research. By event study method can be known is there an impact of abnormal stock price because unanticipated event. Stock price is assumed can reflected the real value of a company, that is a reflection of all future cash flow that discount and include all relevant information.

Keywords: right issue, abnormal return, market model, stock

\section{ABSTRAK}

Artikel menerangkan dampak pengumuman peristiwa right issue terhadap terjadinya abnormal return yang selanjutnya akan mempengaruhi kemakmuran para pemegang saham. Penelitian tentang right issue adalah penelitian event study. Dengan metode event study dapat diketahui apakah ada dampak harga saham yang abnormal (abnormal stock price) akibat dari suatu event yang tidak diantisipasi. Harga saham dianggap dapat merefleksikan nilai sebenarnya suatu perusahaan, yaitu merupakan refleksi dari nilai seluruh arus kas masa depan (future cash flow) yang didiskontokan dan termasuk semua informasi yang relevan.

Kata kunci: right issue, abnormal return,model pasar, saham

\footnotetext{
${ }^{1}$ Staf Pengajar Fakultas Ekonomi Jurusan Manajemen, UBiNus, Jakarta
} 


\section{PENDAHULUAN}

Sistem company listed memungkinkan saham perusahaan lebih marketable. Artinya bahwa apabila terjadi kenaikan harga saham perusahaan di bursa maka pemegang saham dapat memperjualbelikan saham yang belum pernah diperdagangkan. Sistem company listed memungkinkan peningkatan jumlah saham yang diperdagangkan di bursa sehingga kesenjangan permintaan dan penawaran dapat dikurangi yang selanjutnya akan dapat dicapai harga yang wajar.

Bagi perusahaan yang telah go public, alternatif meningkatkan dana di pasar modal adalah melalui right issue. Sejak tahun 1993, strategi penawaran umum terbatas kepada pemegang saham semakin sering digunakan oleh emiten sebagai sumber pembiayaan. Di Indonesia sampai dengan awal 1998, right issue adalah satu-satunya cara bagi perusahaan yang telah listing di bursa untuk menambah ekuitasnya. Right issue merupakan penawaran hak (right) yang diberikan kepada pemegang saham lama untuk membeli saham tambahan pada harga yang lebih rendah daripada harga pasar saat ini. Perusahaan yang menggunakan right issue biasanya menerbitkan satu right untuk setiap saham yang beredar. Dengan demikian, setiap pemegang saham dapat menggunakan right tersebut untuk membeli tambahan equity yang berupa saham umum (common stock) atau saham istimewa (preffered stock) pada harga pemesanan yang lebih rendah daripada harga pasar.

Dana yang diperoleh dari right issue selanjutnya akan digunakan oleh emiten untuk mendanai berbagai macam kepentingan ekonomis. Akibatnya, karakteristik pendapatan dan biaya perusahaan di masa mendatang akan berubah. Investor rasional akan bereaksi terhadap kejadian yang menyebabkan perubahan karakteristik pendapatan dan biaya perusahaan. Investor yang memiliki persepsi bahwa suatu kejadian akan meningkatkan kinerja perusahaan akan berusaha menambah investasinya sedangkan yang memiliki persepsi sebaliknya akan mengurangi atau bahkan melepaskan investasinya. Reaksi itu menyebabkan perubahan harga yang nantinya juga akan mengakibatkan perubahan return bagi investor. Jika pasar modal efisien maka harga saham akan mencerminkan seluruh informasi yang relevan dan bereaksi dengan cepat terhadap setiap informasi baru. Oleh karena itu, apabila setelah pengumuman informasi right issue harga saham menunjukkan kenaikan maka sebenarnya hal itu merupakan gambaran tentang reaksi pasar yang menyetujui transaksi tersebut. Sebaliknya, jika perubahan harga menurun, hal itu merupakan gambaran penolakan pasar terhadap transaksi right issue yang artinya pasar memandang transaksi tersebut akan mengurangi kinerja perusahaan dimasa mendatang.

Penelitian tentang right issue adalah penelitian event study. Dengan metode event study ini dapat diketahui apakah ada dampak harga saham yang abnormal (abnormal stock price) akibat dari suatu event yang tidak diantisipasi. Harga saham dianggap dapat merefleksikan nilai sebenarnya suatu perusahaan, yaitu merupakan refleksi dari nilai 
seluruh arus kas masa depan (future cash flow) yang didiskontokan dan termasuk semua informasi yang relevan. Pengumuman right issue merupakan pengumuman informasi (information release) yang menimbulkan reaksi pasar dan akibat dari pengumuman informasi itu akan membawa dampak positif ataupun negatif terhadap return saham sehingga akan mempengaruhi return bagi investor. Abnormal return akan terjadi jika ada perbedaan return sesungguhnya (actual return) dengan return yang diharapkan (expected return) pada kondisi normal, tanpa adanya suatu event atau pengumuman informasi. Abnormal return positif, jika pasar bereaksi positif terhadap pengumuman informasi. Reaksi positif itu merupakan cerminan dari actual return yang lebih tinggi daripada expected return, begitupun sebaliknya jika abnormal return negatif.

Pada pengumuman right issue diharapkan akan memberikan reaksi positif terhadap pasar. Hal itu karena dengan adanya right issue merupakan berita bagus (good news) bagi investor bahwa perusahaan memiliki peluang investasi yang akan dimanfaatkan. Hal itu berarti bahwa right issue membuktikan kepercayaan investor atau pemegang saham akan masa depan perusahaan. Akan tetapi sebaliknya, right issue akan memberikan dampak yang kurang menguntungkan bagi investor jika pemanfaatan hasil dana yang diperoleh dari right issue dirasa tidak tepat, misalnya untuk melakukan akuisisi internal. Hal itu sesuai dengan penelitian yang pernah dilakukan oleh Conny Tjandra Raharja (1995) bahwa akuisisi eksternal lebih membawa dampak positif, dalam arti memberikan abnormal return positif bagi investor daripada akuisisi internal yang memberikan dampak abnormal return yang tidak signifikan. Begitu pula penelitian yang dilakukan oleh Heli Restiati (1996) bahwa hasil penggunaan right issue untuk akuisisi internal memberikan abnorrnal return negatif.

Ada beberapa faktor yang mempengaruhi terjadinya abnormal return pada right issue, misalnya dampak informasi, harga, redistribusi kemakmuran, signaling. Perubahan faktor itu (informasi, harga, redistribusi kemakmuran, signaling) akan menyebabkan investor bereaksi. Investor yang memiliki persepsi bahwa faktor tersebut akan mampu meningkatkan kinerja perusahaan akan berusaha untuk menambah investasinya sehingga akan dapat meningkatkan harga saham yang selanjutnya akan menyebabkan terjadinya abnormal return.

Dampak right issue terhadap return dapat terjadi pada satu periode tertentu yang diperkirakan akan terpengaruh dengan adanya suatu event yang dalam hal ini event-nya adalah pengumuman right issue. $\mathrm{t}=0$ adalah tanggal event, announcement date of right issue (tanggal pengumuman right issue), event window adalah t setelah ataupun sebelum $\mathrm{t}$ $=0$ yang dapat ditentukan selama beberapa hari kerja transaksi di bursa, biasanya $\mathrm{t}=-10$ berarti 10 hari kerja transaksi sebelum announcement date sedangkan $\mathrm{t}=10$, berarti 10 hari kerja transaksi setelah tanggal pengumuman. 
Berdasarkan uraian latar belakang tersebut, dapat dirumuskan beberapa masalah yang relevan dengan topik penelitian sebagai berikut.

1. Apakah terjadi abnormal return positif pada periode pengumuman right issue bagi perusahaan yang menggunakan dana right issue untuk akuisisi eksternal?

2. Apakah tidak terjadi abnormal return yang signifikan pada periode pengumuman right issue bagi perusahaan yang menggunakan dana right issue untuk akuisisi internal?

3. Faktor apa yang mempengaruhi terjadinya cumulative abnormal return sehubungan dengan right issue?

\section{Hipotesis Penelitian}

1. a. Diperoleh abnormal return positif pada periode announcement date of right issue untuk perusahaan yang akan menggunakan dana right issue untuk akuisisi eksternal.

b. Tidak diperoleh abnormal return yang signifikan pada periode announcement date of right issue untuk perusahaan yang akan menggunakan dana right issue untuk akuisisi internal.

2. Rasio ekuitas baru yang diterbitkan, size perusahaan, varians return, harga penawaran, rasio utang, kontribusi pemodal, likuiditas, kondisi pasar, dan tujuan penggunaan dana, mempengaruhi terjadinya CAR (cumulative abnormal return) pada tanggal pengumuman.

Hipotesis ke 2 dapat dinyatakan dalam persamaan sebagai berikut.

$$
\begin{aligned}
\text { CAR }_{\mathrm{i}}(-\mathrm{t}, 0) & =\mathrm{a}_{0}+\mathrm{a}_{1} \text { INVEST }_{\mathrm{i}}+\mathrm{a}_{2} \text { SIZE }_{\mathrm{i}}+\mathrm{a}_{3} \mathrm{VAR}_{\mathrm{i}}+{ }_{4} \mathrm{OFFER}+\mathrm{a}_{5} \mathrm{D}_{\mathrm{DTOAi}_{\mathrm{i}}}+ \\
& \mathrm{a}_{6} \text { CONTR }_{\mathrm{i}}+\mathrm{a}_{7} \text { LIQUID }_{\mathrm{i}}+\mathrm{a}_{8} \text { MARKET }_{\mathrm{i}}+\mathrm{a}_{9} \mathrm{D}_{\text {ACQi }}+\mathrm{e}
\end{aligned}
$$

\section{Metode Penelitian}

Dalam melakukan penelitian event study dengan topik right issue ini, peneliti menggunakan kerangka konsep pengujian hipotesis statistikal. Untuk menguji hipotesis satu (1.a.) dan hipotesis satu (1.b.), digunakan model matematis. Untuk menguji hipotesis dua (2), digunakan model hubungan antara variabel independen dengan variabel dependen adalah dalam bentuk regresi linear berganda. Pertimbangannya adalah bahwa ukuran variabel bebas dan variabel terikat adalah dalam skala interval (metrik), model itu memiliki bentuk yang sederhana dan umum dipakai baik dari segi penghitungan maupun dari segi interpretasinya. 


\section{PEMBAHASAN}

\section{Definisi Operasional Variabel}

Dalam penelitian ini yang dimaksud dengan dengan shareholder wealth (kemakmuran pemegang saham) adalah tercermin dari besarnya cumulative abnormal return yang dihasilkannya akibat dari adanya pengumuman right issue. Adapun faktor yang menyebabkan terjadinya abnormal return sehubungan dengan right issue tersebut adalah hal berikut.

INVEST : Ukuran tambahan modal yang disetujui oleh pemegang saham lama dibandingkan dengan banyaknya saham perusahaan yang beredar.

SIZE : Ukuran besarnya perusahaan yang dihitung dengan logaritma dari banyaknya lembar saham yang beredar dikalikan dengan harga saham satu bulan sebelum tanggal pengumuman.

VARIANCE : Varians return perusahaan $i$, dihitung dari varians return harian saham $i$ selama hari $-200 \mathrm{~s} / \mathrm{d}-51$.

OFFER : Harga penawaran sebagai fraksi dari harga saham $i$, ditentukan dari rasio harga penawaran dengan harga penutupan satu bulan sebelum hari pengumuman.

DTOA : Variabel dummy yang berdasarkan rasio debt/asset, DTOA=1 berarti perusahaan memiliki rasio debt/asset diatas median sampel, sedang jika $\mathrm{DTOA}=0$ berarti perusahaan memiliki rasio debt/asset dibawah median sampel.

CONTRIBUTION : Ukuran difusi kepemilikan perusahaan, dihitung dari banyaknya shareholder sebelum penawaran.

LIQUIDITY : Ukuran likuiditas saham perusahaan, diukur dengan rata-rata volume perdagangan harian setiap saham sampel satu tahun sebelum penawaran dibagi dengan jumlah saham beredar.

MARKET : Ukuran performance pasar saham sebelum issue, menunjukkan cumulative average return pasar saham periode $\mathrm{t}=-50 \mathrm{~s} / \mathrm{d} \mathrm{t}=-1$.

ACQUISITION : Variabel dummy yang menunjukkan tujuan penggunaan dana right issue yang umumnya untuk operasional, investasi dalam bentuk akuisisi. AKUISISI=1 berarti untuk akuisisi eksternal, AKUISISI $=0$ berarti untuk akuisisi internal.

CAR : Merupakan Cumulative Abnormal Return dari periode hari -10 sampai dengan +10

\section{Populasi dan Sampel}

Data yang digunakan dalam penelitian adalah data selama periode semester I 1993 sampai dengan semester I 1997 (9 semester). Tahun 1997 diambil hanya sampai semester I karena pada awal semerter II (sekitar bulan Agustus 1997) sudah mulai terjadi 
krisis ekonomi sehingga mempengaruhi kinerja BEJ yang sudah tidak realistis lagi, misalnya harga saham sudah di bawah nilai nominalnya. Populasi right issue diteliti dari semua perusahaan yang telah go public dan terdaftar di BEJ selama periode semester I 1993 sampai dengan semester I 1997 yang pernah melakukan right issue, yakni sebanyak 128 issuer. Ada 34 issuer yang menggunakan dana right issue untuk akuisisi sehingga itulah yang diambil sebagai sampel dalam penelitian ini. Jika dana digunakan untuk akuisisi internal dan juga untuk akuisisi eksternal maka untuk menentukan apakah akan dimasukkan sebagai akuisisi internal ataukah sebagai akuisisi eksternal dilihat dari persentasenya. Jika dananya digunakan $>50 \%$ untuk akuisisi internal maka akan dianggap sebagai akuisisi internal, begitu juga akan dianggap sebagai akuisisi eksternal, jika dana yang digunakan > 50\% untuk melakukan akuisisi eksternal. Dari 34 sampel emiten tersebut, ada $82 \%$ atau 28 emiten yang melakukan akuisisi internal sedang sisanya $18 \%$ atau 6 emiten melakukan akuisisi eksternal.

\section{Pengolahan dan Teknik Analisis Data}

\section{Model}

Model yang digunakan untuk membahas permasalahan 1 dan 2 yakni menguji dampak right issue terhadap return saham adalah Model Market. Model yang digunakan untuk menghitung Abnormal Return (AR) tiap saham selama hari event $\mathrm{t}$, yaitu:

$$
A R_{i t}=R_{i t}-\left[\alpha_{i}+\beta_{i} R_{m t}\right]
$$

Keterangan :

$\mathrm{AR}_{\mathrm{it}}=$ Abnormal return saham $i$ pada hari $t$

$\mathrm{R}_{\mathrm{it}} \quad=$ Return saham individu $i$ pada hari $t$

$\mathrm{R}_{\mathrm{mt}} \quad=$ Return pasar pada hari $t$

$\alpha$ dan $\beta=$ Intercept dan slope regresi linear antara return saham individu $i$ dengan return pasar selama estimation window

Return saham individu ditentukan dari perbedaan harga penutupan saham pada hari $t$ dengan hari $t_{-1}$.

$$
\mathbf{R}_{\mathrm{it}}=\frac{\mathbf{P}_{\mathrm{it}}-\mathbf{P}_{\mathrm{it}-1}}{\mathbf{P}_{\mathrm{it}-1}}
$$

Keterangan:

$\mathrm{R}_{\mathrm{it}} \quad=$ Return saham individu $i$ pada hari $t$

$\mathrm{P}_{\mathrm{it}} \quad=$ Harga penutupan saham $i$ pada hari $t$

$\mathrm{P}_{\mathrm{it}-1}=$ Harga penutupan saham $i$ pada hari $t-1$ 
Untuk menganalisis keseluruhan cumulative abnormal return (Permasalahan 3), digunakan analisis cross sectional abnormal return dalam bentuk regresi yang dapat membantu membedakan berbagai hipotesis (information, price pressure, wealth redistribution, signaling effects) dan juga untuk mengidentifikasi faktor penyebab cumulative abnormal return.

$$
\begin{aligned}
\text { CAR }_{\mathrm{i}}(-\mathrm{t}, 0)= & \mathrm{a}_{0}+\mathrm{a}_{1} \text { INVEST }_{\mathrm{i}}+\mathrm{a}_{2} \text { SIZE }_{\mathrm{i}}+\mathrm{a}_{3} \text { VAR }_{\mathrm{i}}+\mathrm{a}_{4} \mathrm{OFFER}_{\mathrm{i}}+\mathrm{a}_{5} \mathrm{D}_{\text {DTOAi }}+ \\
& \mathrm{a}_{6} \text { CONTR }_{\mathrm{i}}+\mathrm{a}_{7} \operatorname{LIQUID}_{\mathrm{i}}+\mathrm{a}_{8} \mathrm{MARKET}_{\mathrm{i}}+\mathrm{a}_{9} \mathrm{D}_{\text {ACQi }}+\mathrm{e}
\end{aligned}
$$

\section{Uji Hipotesis}

\section{a. Uji Signifikansi Abnormal Return}

Untuk menguji hipotesis 1 (a dan b), digunakan uji statistik $\mathrm{t}$ - test untuk menguji signifikansi rata-rata abnormal return (AAR=Average Abnormal Return) masingmasing kelompok sampel untuk akuisisi eksternal (hipotesis 1a) dan kelompok sampel untuk akuisisi internal (hipotesis $1 \mathrm{~b}$ ). Rumus uji - $\mathrm{t}$ yang digunakan adalah sebagai berikut.

$$
\mathbf{t}=\frac{\mathbf{A A R}}{\sigma / \sqrt{ } \mathbf{n}}
$$

Keterangan:

$$
\begin{array}{ll}
\text { AAR } & =\text { Average Abnormal Return (Abnormal Return rata-rata) } \\
\sigma & =\text { Standar deviasi } \\
\mathrm{n} & =\text { Banyaknya sampel }
\end{array}
$$

Sehingga hipotesis statistiknya adalah sebagai berikut.

Kelompok sampel untuk akuisisi eksternal:

$\mathrm{H}_{0}: \mathrm{AAR} \leq 0$

$\mathrm{H}_{\mathrm{a}}: \mathrm{AAR}>0$

$\mathrm{H}_{0}$ ditolak jika t-stat $>\mathrm{t}_{\alpha . d f}$

Kelompok sampel untuk akuisisi internal:

$\mathrm{H}_{0}: \mathrm{AAR} \neq 0$

$\mathrm{H}_{\mathrm{a}}: \mathrm{AAR}=0$

$\mathrm{H}_{0}$ ditolak jika $\quad-\mathrm{t}_{\alpha . \text { df }}<\mathrm{t}$-stat $<\mathrm{t}_{\alpha . \mathrm{df}}$

Dalam uji signifikansi abnormal return, tingkat $\alpha$ yang digunakan adalah mulai $1 \%$, $5 \%$, dan $10 \%$. 


\section{b. Uji Multikolinearitas}

Multikolinearitas (multicolinearity test) digunakan untuk menguji apakah ada hubungan yang erat antar variabel bebas dalam fungsi regresi tersebut. Untuk mengetahui ada tidaknya multikolinearitas, akan digunakan perhitungan koefisien korelasi Pearson (Gujarati, 1988) dan perhitungan Variance Inflation Factor (VIF) (Dielman, 1991). Jika nilai VIF tinggi diantara variabel bebas maka menunjukkan bahwa variabel tersebut saling berkorelasi. Hal itu berarti terjadi multikolinearitas. Umumnya, akan dikatakan terjadi multikolinearitas yang serius jika nilai VIF > 10 (Dielman, 1991). Adapun rumus koefisien korelasi Pearson adalah sebagai berikut.

$$
r=\frac{n \Sigma X Y-\Sigma X \Sigma Y}{\sqrt{n \Sigma X^{2}-\left(\Sigma X^{2}\right) \sqrt{n} \Sigma Y^{2}-\left(\Sigma Y^{2}\right)}}
$$

Keterangan :

$\mathrm{r} \quad=$ Koefisien korelasi

$\mathrm{n}=$ Jumlah sampel

$\mathrm{X}=$ Variabel independen

$\mathrm{Y}=$ Variabel dependen

Rumus VIF adalah sebagai berikut.

$$
\mathrm{VIF}=\frac{1}{\left(1-\mathrm{R}_{\mathrm{i}}{ }^{2}\right)}
$$

Keterangan:

VIF = Variance Inflation Factor

$\mathrm{R}_{\mathrm{i}}{ }^{2}=$ Koefisien regresi berganda apabila variabel independen ke-i diprediksi dari variabel independen yang lain

\section{Hasil Penelitian}

Hasil penelitian menunjukkan hal berikut.

1. Penentuan tanggal pengumuman right issue (event date atau $\mathrm{t}_{0}$ ) seharusnya berdasarkan pertimbangan bahwa event date adalah tanggal pertama kali informasi tersebar secara publik. Berdasarkan atas pertimbangan tersebut maka event date-nya adalah saat tersebarnya informasi di media massa tentang akan diadakannya RULBPS. Penentuan event date itu dengan alasan inilah saat pertama kali investor yang aktif mencari informasi (well-informed investor) menangkap informasi. Sebagai pembanding event date adalah tanggal dimana informasi baru direspons oleh investor yang pasif dalam mencari informasi (unwell-informed), yaitu tanggal terjadinya pelaksanaan hak/right (ex-right date). 
Tabel 1 Daftar Event Right Issue Emiten

\begin{tabular}{|c|c|c|c|}
\hline NO. & EMITEN & $\begin{array}{c}\text { RULBPS } \\
\text { ANNOUNCEMENT } \\
\text { DATE }\end{array}$ & $\begin{array}{l}\text { EX-RIGHT } \\
\text { DATE }\end{array}$ \\
\hline 1 & ADMG (ANDAYANI MEGAH) & $16-9-96$ & 7/10/96 \\
\hline 2 & ASGR (ASTRA GRAPHIA) & $13-6-96$ & $16-7-96$ \\
\hline 3 & BAYU (BAYU BUANA) & $13-6-93$ & 8/7/93 \\
\hline 4 & BNBR (BAKRIE BROTHER) & $12 / 4 / 93$ & $10 / 5 / 93$ \\
\hline 5 & BNBR (BAKRIE BROTHER) & $12 / 6 / 94$ & 28-07-94 \\
\hline 6 & BNII ( BANK INT. INDONESIA) & $12 / 12 / 96$ & 3/1/97 \\
\hline 7 & CPPR (CP. PRIMA) & $28-5-96$ & $18-6-96$ \\
\hline 8 & DSST ( DARMALA SAKTI) & $29-5-94$ & $20-6-94$ \\
\hline 9 & DVLA (DARYA VARIA) & $31-3-96$ & $19-4-96$ \\
\hline 10 & GJTL (GAJAH TUNGGAL) & 9/9/96 & $30-9-96$ \\
\hline 11 & GRIV (GREAT RIVER IND.) & $15-1-96$ & $5 / 2 / 96$ \\
\hline 12 & GSMF (GJH SURYA MF) & $31-3-94$ & $22-4-94$ \\
\hline 13 & IGAR (IGAR JAYA) & 11/6/95 & $30-6-95$ \\
\hline 14 & INDR (INDORAMA SYN.) & 4/5/95 & 26-5-95 \\
\hline 15 & JIHD (JKT. INT. HOTEL\&DEV.) & $15-5-96$ & 5/6/96 \\
\hline 16 & KLBF (KALBE FARMA) & 29-3-93 & $20-04-93$ \\
\hline 17 & LION (LION METAL) & 5/6/96 & $26-6-96$ \\
\hline 18 & LPLD (LIPPO LAND DEV.) & $11 / 9 / 94$ & 3/10/94 \\
\hline 19 & LPLI (LIPPO LIFE) & 10/6/96 & $1 / 7 / 96$ \\
\hline 20 & LPPS (LIPPO SEC.) & $12 / 6 / 97$ & 3/7/97 \\
\hline 21 & MLND (MULIALAND DEV.) & $15-5-96$ & $5 / 6 / 96$ \\
\hline 22 & MLPL (MULTIPOLAR) & 6/6/96 & $28-6-96$ \\
\hline 23 & MLPL (MULTIPOLAR) & 8/6/97 & $30-6-97$ \\
\hline 24 & MTFN (BAKRIE BROTHER MF) & $21-1-94$ & $11 / 2 / 94$ \\
\hline 25 & MTFN (BAKRIE BROTHER MF) & 24-9-95 & $13-10-95$ \\
\hline 26 & OM-RE (OMETRACO REALTY) & $14-11-96$ & $5 / 12 / 96$ \\
\hline 27 & POOL (POOL ASURANSI) & $14-6-94$ & $6 / 7 / 94$ \\
\hline 28 & PTRA (PUTRA SRY. PERKASA) & $16-1-96$ & $6 / 2 / 96$ \\
\hline 29 & PWON (PAKUWON JATI) & $13-6-94$ & $5 / 7 / 94$ \\
\hline 30 & SHDA (SARI HUSADA) & $17-4-94$ & $6 / 5 / 94$ \\
\hline 31 & SMCB (SEMEN CIBINONG) & $12 / 6 / 94$ & $4 / 7 / 94$ \\
\hline 32 & SMGR (SEMEN GRESIK) & 5/7/95 & $26-7-95$ \\
\hline 33 & SONA (SONA TOPAZ) & $4 / 5 / 95$ & $24-5-95$ \\
\hline 34 & TMPI (TELAGA MAS PI.) & $26-2-97$ & $19-3-97$ \\
\hline
\end{tabular}

2. Jika $t_{0}$ adalah tanggal pengumuman RULBPS ternyata pada pasar modal di Indonesia (BEJ) terjadi abnormal return negatif dan positif yang signifikan pada periode sebelum $\mathrm{t}_{0}$ tetapi, setelah $\mathrm{t}_{0}$ tidak terjadi lagi abnormal return. Hal itu ada kemungkinan terjadi insider trading. Akan tetapi, jika dikelompokkan menurut tujuan penggunaan dana untuk akuisisi eksternal dan internal dapat disimpulkan sebagai berikut. 
a. Untuk akuisisi eksternal, terbukti hipotesis dengan terjadinya abnormal return positif yang signifikan pada periode event window (lima hari setelah event date).

b. Untuk akuisisi internal, tidak terbukti hipotesis karena ternyata terjadi abnormal return positif dan negatif yang signifikan pada periode event window (lima hari dan satu hari sebelum event date).

3. Jika $t_{0}$ adalah tanggal pelaksanaan right, ternyata terjadi abnormal return negatif pada periode sebelum dan setelah $\mathrm{t}_{0}$. Hal itu mendukung penemuan tentang dampak right issue terhadap abnormal return di berbagai negara maju (AS dan Eropa Barat) tentang abnormal return negatif di seputar event window. Jika ditinjau dari tujuan penggunaan dana maka dapat ditarik simpulan berikut.

a. Untuk akuisisi eksternal, tidak terbukti hipotesis karena ternyata terjadi abnormal return negatif yang signifikan pada periode event window.

b. Untuk akuisisi internal, tidak terbukti hipotesis karena selama event window terjadi abnormal return negatif yang signifikan

4. Dari sembilan variabel yang mempengaruhi terjadinya CAR $\left(\mathrm{t}_{0}=\right.$ tanggal Pengumuman RULBPS), hanya ada dua faktor saja yang berpengaruh secara signifikan terhadap terjadinya CAR, yakni OFFER dan LIQUID (likuiditas saham). Jika $\mathrm{t}_{0}=e x$-right date maka variabel yang berpengaruh sangat signifikan terhadap CAR adalah OFFER, DTOA, CONTR., LIQUID, MARKET.

5. Dampak informasi (information effect) yang tercermin pada variabel invest, contribution, market terbukti hipotesisnya melalui dua variabel, yakni contribution dan market untuk $\mathrm{t}_{0}=$ ex-right date. Pada BEJ, makin terkonsentrasi difusi kepemilikan mengindikasikan dampak informasi yang kuat. Begitu pula makin besar return pasar atau makin tinggi tingkat kenaikan IHSG semakin kuat dampak informasinya. Invest, semakin besar tambahan dana yang diperlukan mengindikasikan adanya informasi tentang cash flow yang negatif dari issuer. Sedangkan jika $\mathrm{t}_{0}=$ tanggal pengumuman RULBPS tidak terbukti hipotesisnya.

6. Dampak tekanan harga (price pressure effect) tercermin pada variabel size, variance, liqudity tidak terbukti hipotesisnya. Hanya variabel LIQUID yang berpengaruh pada BEJ dan bertolak belakang dengan hipotesisnya (tanda negatif) baik $\mathrm{t}_{0}=$ tanggal pengumuman RULBPS maupun $\mathrm{t}_{0}=$ ex-right date. Semakin likuid saham semakin besar dampak reaksi harga saham.

7. Dampak redistribusi kemakmuran pemegang saham (wealth redistribution effect) yang tercermin pada variabel DTOA terbukti jika $\mathrm{t}_{0}=e x$-right date. Berdasarkan hasil penemuan ini bahwa emiten yang memiliki rasio utang terhadap aset yang lebih besar dari nilai median seluruh sampel emiten mengimplikasikan terjadi transfer kemakmuran dari shareholder kepada bondholder.

8. Dampak signaling (signaling effect) yang tercermin pada variabel offer dan acquisition tidak terbukti. Akan tetapi, penemuan penelitian ini berlawanan dengan hipotesis dampak signaling pada variabel OFFER baik $\mathrm{t}_{0}=$ tanggal pengumuman RULBPS maupun $\mathrm{t}_{0}=$ ex-right date. Hal itu karena berdasarkan hasil penemuan di 
BEJ ini bahwa semakin tinggi harga penawaran semakin kecil abnormal return. Hal itu merupakan signal bahwa investor sangat concern terhadap harga pemesanan.

9. Secara keseluruhan, variabel OFFER dan LIQUID secara bersamaan signifikan berpengaruh terhadap CAR untuk $\mathrm{t}_{0}=$ tanggal pengumuman RULBPS dapat memberi penjelasan tentang variasi perubahan CAR dengan tingkat 13,69\% sedangkan jika $\mathrm{t}_{0}=e x$-right date variabel OFFER, DTOA, CONTR., LIQUID, MARKET secara bersamaan dapat menjelaskan variasi perubahan CAR sebesar $92,67 \%$.

10. Perbedaan hasil penemuan ini dengan hasil penemuan sebelumnya Conny Chandra Raharja (1995) dan Heli Restiati (1996), terutama untuk hasil temuan akuisisi internal karena perbedaan periode penelitian yang lebih lama.

\section{PENUTUP}

Terdapat beberapa faktor atau variabel independen yang tidak signifikan berpengaruh terhadap variabel dependen. Oleh karena itu, masih ada kemungkinan melakukan penelitian lebih lanjut tentang beberapa variabel independen tersebut dan penentuan $\mathrm{t}_{0}$ berdasarkan tanggal lain yang mungkin paling tepat mengindikasikan pertama kali investor menangkap informasi secara publik guna mendukung dan melengkapi penelitian ini.

Penentuan periode CAR sebelum event date $(-10,0)$ dapat dimodifikasi dengan CAR setelah event date dengan pertimbangan dipilh saat $t$ yang signifikan sehingga diperoleh hasil penelitian yang lebih lengkap. Di samping itu juga, penentuan periode even window yang dapat diperpanjang $(>+/-10$ hari) atau diperpendek $(<+/-10$ hari) dengan harapan akan ditemukan hasil yang lebih variatif dan memperkuat penemuan ini.

Ditinjau dari besarnya nilai $\mathrm{R}^{2}$ yang agak terlalu rendah berarti masih ada faktor lain yang mempengaruhi secara lebih signifikan terhadap CAR. Oleh karena itu, ada kemungkinan faktor lain, baik mikro maupun makro yang mempengaruhi CAR. Oleh karena itu, masih dapat dilakukan penelitian lebih lanjut yang mampu mengidentifikasikan lebih tepat lagi variabel independen lainnya. 


\section{DAFTAR PUSTAKA}

Bayless, Mark and Susan Chaplinsky. "Is There a Window Opportunity for Seasoned Equity Issuance?” Journal of Finance (March 1996), 253 - 277.

Bodie, Zvi and Alex kane. 1996. Investment. $3^{\text {rd }}$ Edition. Chicago: Irwin.

Brown, S.J. and J.B. Warner. 1980. “Measuring Security Price Performance.” Journal of Financial Economics (Juni), 205 - 258.

Damodaran, Aswath. 1997. Corporate Finance: Theory and Practice. New York: John Wiley and Sons.

Emery, Douglas R. and John D. Finnerty. 1997. Corporate Financial Management. $1^{\text {st }}$ Edition. Prentice Hall, Inc.

French, Kenneth R. and Richard Roll. 1986. "Stock Return Variance: The Arrival of Information and the Reaction of Trader." Journal of Financial Economics 17, 5 $-26$.

Hanafiah, Mamduh. 1998. “Efisiensi Emisi Saham Baru di BEJ (1989 - 1994).” Kelola 17/VII, $88-106$.

Hermanto, Bambang. 1998. "Nominal Stock Return Volatility on the Stock Exchange and Changes in Government Policy." Disertasi. The University of Birmingham, England.

Johnson, Dana J. et all. "Seasoned Equity Offering for New Investment and the Information Content of Insider Trades.” Journal of Financial Research (Spring 1996), $96-103$.

Raharja, Conny Chandra. 1995. "Dampak Akuisisi terhadap Kemakmuran Pemegang Saham: Perbandingan Akuisisi Eksternal dan Internal.” Tesis, Program Studi Magister Manajemen UGM, Yogyakarta.

Restiati, Heli. 1996. "Mendeteksi Pengaruh Informasi Akuisisi terhadap Nilai Perusahaan: Suatu Pengamatan pada Bursa Efek Jakarta.” Skripsi, Sekolah Tinggi Akuntansi Negara (STAN), Jakarta.

Tsangarakis, Nickolas V. 1996. "Shareholder Wealth Effect of Equity Issues in Emerging Market: Evidence from Right Offerings in Greece.” Journal of Financial Management, Vol. 25, No. 3, Autumn 1996, 21 - 32. 